\title{
Preferred Language in Business: An Analysis of Shop Signs in Kuantan City, Malaysia
}

Muhammad Harriz Zaini, Azlini Razali, Jun Nirlawati Mohd Sahidol \& Kamisah Ariffin

To Link this Article: http://dx.doi.org/10.6007/IJARBSS/v11-i10/10744

DOI:10.6007/IJARBSS/v11-i10/10744

Received: 23 August 2021, Revised: 25 September 2021, Accepted: 04 October 2021

Published Online: 29 October 2021

In-Text Citation: (Zaini et al., 2021)

To Cite this Article: Zaini, M. H., Razali, A., Sahidol, J. N. M., \& Ariffin, K. (2021). Preferred Language in Business: An Analysis of Shop Signs in Kuantan City, Malaysia. International Journal of Academic Research in Business and Social Sciences, 11(10), 939-948.

Copyright: (c) 2021 The Author(s)

Published by Human Resource Management Academic Research Society (www.hrmars.com)

This article is published under the Creative Commons Attribution (CC BY 4.0) license. Anyone may reproduce, distribute, translate and create derivative works of this article (for both commercial and non-commercial purposes), subject to full attribution to the original publication and authors. The full terms of this license may be seen

at: http://creativecommons.org/licences/by/4.0/legalcode

Vol. 11, No. 10, 2021, Pg. $939-948$

Full Terms \& Conditions of access and use can be found at http://hrmars.com/index.php/pages/detail/publication-ethics 


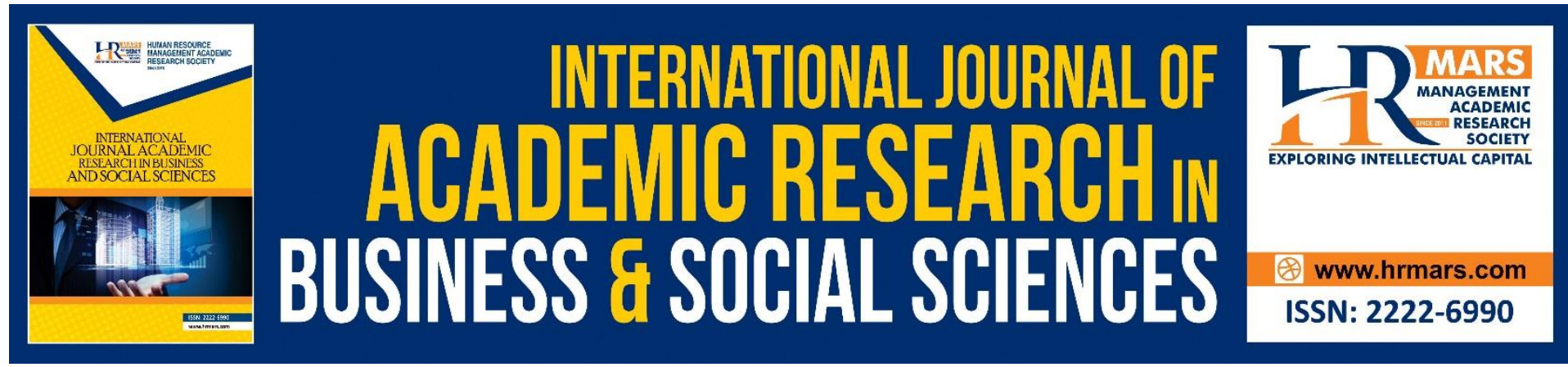

\title{
Preferred Language in Business: An Analysis of Shop Signs in Kuantan City, Malaysia
}

\author{
Muhammad Harriz Zaini, Azlini Razali, Jun Nirlawati Mohd \\ Sahidol \& Kamisah Ariffin \\ Academy of Language Studies, Universiti Teknologi MARA Pahang, Malaysia \\ Email: harrizzaini@uitm.edu.my, azlini@uitm.edu.my,junms88@uitm.edu.my, \\ kamisah@uitm.edu.my
}

\begin{abstract}
The linguistic landscape of a territory may disclose information on the power and vitality of certain languages within the community in that particular territory. This study analyses the language use in shop signs along two main streets in the multilingual city of Kuantan, Malaysia. 179 still images of shop signs in the area are captured and procured for the data. A textual analysis on the shop sign images based on the language patterns of monolingual, bilingual and multilingual framework is carried out. The frequencies of the language patterns are used and categorized based on the framework to determine the proprietors' language preferences for their shop signs. The analysis indicates that the number of bilingual and multilingual signs combined far exceeded the number of monolingual signs. The analysis further shows that bilingual signs of Bahasa Malaysia (BM) and English are the most preferred choices for the shop signs despite the enactment of the National Language Policy, soliciting that BM must be used for the public signs. Such preference implies the proprietors' keenness in embracing the image of modernity and sophistication for their shops, indicating that language use in business in business cannot be simply regulated by any policy. Rather, it is moving towards personal freedom, signifying the business community solidarity of which language(s) is deemed appropriate for their businesses despite the mandatory policy.
\end{abstract}

Keywords: Business Naming, Shop Names, Language Use and Preferences

\section{Introduction}

The study of the linguistic landscape (LL) of a territory is important as it functions as the emblem of societies, communities and regions. According to Landry and Bourhis (1997), LL can be defined as an extensive view of languages, in specified areas, as it is used in various signages which revolve around businesses, official matters or even isolated roads. How certain roads and shop names are named depend on the locality, ethnicity or even decided by the authority in charge of the particular area. Landry and Bourhis (1997) further reiterates that the language choice in public signage shows the status in the community of the language used and, as such, marks the relative power and status of the linguistic communities in a particular territory. Thus, LL is also seen as the social meaning associated with the display of linguistic signage in material environment (Shang \& Guo, 2016). 
Most countries have distinctive rules and policies for language to be used in the public signs. In multilingual Malaysia, the National Language Act has been enacted to protect the supremacy of Bahasa Malaysia or the Malay Language (BM, henceforth) as the national language of the country. The enactment of the Local Council by-laws (Undang-undang kecil Majlis Perbandaran) and the National Language Act (Akta Bahasa Kebangsaan) stipulates that the use of $\mathrm{BM}$ is mandatory for the public signboards and road names. English words (or other languages) are only permissible if they are not too prominent as compared to BM. However, studies have noted that this is quite wide off the mark (Manan et al., 2015; Hasan et al., 2015; Ariffin et al., 2019; Husin, et al., 2019; Omar et al., 2020). These studies find that other languages, other than BM, are commonly used in the public signs, particularly in the business domains despite the policy solicited.

Most studies on the LL in Malaysia have focused on language use and preference in big and metropolitan cities like Kuala Lumpur, where the choice can be more or less predicted due to the multilingual population and concentration of international businesses. Studies on towns and cities in the East-Coast part of the country, where development is considered slower compared to the West-Coast, have been scarce. Thus, the present study aims to fill the gap by examining the language use in the shop signs in Kuantan, a city located in the East-Coast of Peninsular Malaysia. It is hoped that the findings will add some knowledge to the field, particularly in understanding language choice and preferences in the business domain.

\section{The Linguistic Landscape of Shop Signs}

Jaworski and Thurlow (2010) assert that the study of the linguistic landscape (LL) can inform our understanding of a range of intellectual issues above and beyond the mere analysis of linguistic form. The $L L$ affords valuable insight into the underlying political, ideological, and ethnolinguistic tensions that govern the official signage policy and practice (David \& Manan, 2016). As put forward by Gorter (2006); Shohamy (2006), the language used on official signs can convey messages about its importance, authority, significance, and relevance in a community or society. The presence or absence of a certain group's language in LL can show the societal approaches towards the language and its speakers, as well as mark the ethnolinguistic vitality of the group inhibiting the territory.

As territories have now become borderless, language use has become arbitrary. Thus, as Bolton (2012) argues, research in LL may help in understanding the rapid changes in urban landscapes as well as the increase in the number of multilingual worlds. Wang and Xu (2018) agree that $L L$ is not only a method to show the realities of the usage of language, but also a window to see the strain between practices, beliefs, and managements in language policy, which can be seen especially in a society that is multilingual.

In the business domain, language use has gone beyond nationalism and culture, regardless of whether certain language use is mandated by the authority or not. In the face of a multilingual audience, shop names are suitable in showcasing the business owners' way to address the language issue (Gorter, 2006). For example, in Malaysia, although BM has been solicited mandatory on public signboards, other languages spoken and recognised by the people in the country, such as English, Mandarin and Tamil and even Korea, Japanese and Spanish, can be found on the signboards. The languages may be used prominently on their own, or combined (Manan et al., 2015; Ariffin et al., 2019; Omar et al., 2020). 
Along the same line, in the context of Singapore, the official policies barely touch upon the choice of language on public signs. Although the official signs for public spaces are seen mainly in English, which is due to the country's macro language policy, non-official and private signs display a variety of language use patterns that are totally different from the official signs (Shang \& Guo, 2016). Shang and Guo also believe that since no official policy is mandated regarding the language presence on public signage, the patterns of language use, especially in the domains of non-government, tend to be manifold. According to Tan (2011), private signs in Singapore are predominantly represented in English, but there is an increasing tendency to use foreign languages such as French, Spanish and Italian in the main elements of building names.

Language use in the business domain also shows that influential languages are preferred over the mandated ones because of the benefits that they bring to the business. In Iran, for instance, the use of foreign language is limited in the mass media especially on television, which holds the highest number of media users (Khosravizadeh \& Sanjareh, 2011). However, because of its values, status and benefits to business, people still widely use English words in brand names and shop signs in that country. In the same vein, it has been observed that English has a marked visibility and saliency on the signs in Bangkok, Thailand (Huebner, 2006). This shows that LL can demonstrate and highlight the spread of English either as an influential language, or as a source of information for international visitors where English is not a native language (Saleem, 2018).

\section{The Study}

The objective of this study is to observe the patterns of language use and preference in shop signs in the East-Coast city of Kuantan, Malaysia. Specifically, it seeks to answer the following research questions:

1. What are the patterns of language use on the shop signs in Kuantan City?

2. What are the preferred language(s) on the shop signs in Kuantan City?

3. What are the factors influencing the language use and preference on the shops signs in Kuantan City?

\section{Description of Research Area}

Kuantan, the capital state of Pahang, is located in the East Coast of Malaysia. It was proclaimed as a city on $21^{\text {st }}$ February 2021 and is considered the beacon of the East Coast having succeeded in attracting foreign investors, businesses and tourists. An estimation of 103,000 people lived Kuantan as of the 2020 census. Of this, $80.6 \%$ are Bumiputeras, $15.9 \%$ Chinese, $3.1 \%$ Indian and $0.4 \%$ for other ethnics. The major socio-economic groups in this city are administrative and industrial employees, retailers, small scale business operators, and college or university students.

The research areas comprised of two main streets in the city, which are Jalan Bukit Ubi and Jalan Teluk Sisek, where the new developed business parks are established. The areas consist of major shopping centres, prestigious hotels, a convention centre and higher education centres. Scores of residential areas for the low, middle and also the high bracket income groups can be found in this area. 


\section{Methodology}

This study involves a textual analysis on the language use and choice in the digital still images of 179 shop signs captured in the research areas. Only shop signs that belonged to private proprietors are procured as the data for this study. Signs from the chain or multinational stores are excluded from the data selection as the choice of the language use would not have been made locally or personally.

The data are analysed based on the patterns of language use on the shop signs. The signs are categorised into monolingual, bilingual and multilingual language use. To determine the patterns of language use, the frequency count of each pattern is applied. Table 1 describes the framework for analysing the patterns of language use in the shop signs while Figure 1 below shows some examples of these patterns. It is important to note that the Jawi/Arabic script used in the shop signs is not of another language. It is just a scripture of the language use in the shop signs in Jawi as this has been made mandatory by the Pahang Municipal Council in its effort to preserve the Jawi scripture as one of the Malay culture.

Table 1: Framework for Analysis

\begin{tabular}{lll}
\hline Category & Description & Examples \\
\hline Monolingual & $\begin{array}{l}\text { Only one language is used (BM, English, } \\
\text { Chinese, Tamil, etc.) }\end{array}$ & Restoran Baina Nasi Kerabu \\
\hline Bilingual & Two languages are used (BM + English, & $\begin{array}{l}\text { Kedai Serbaneka Rainbow } \\
\text { English + Chinese, etc.) }\end{array}$ \\
\hline Multilingual & Three or more languages are used (BM + & Kedai Mence Shop \\
& English + Chinese, etc.) & Bestware Trading 最佳软件 \\
& & 交易 \\
\hline
\end{tabular}
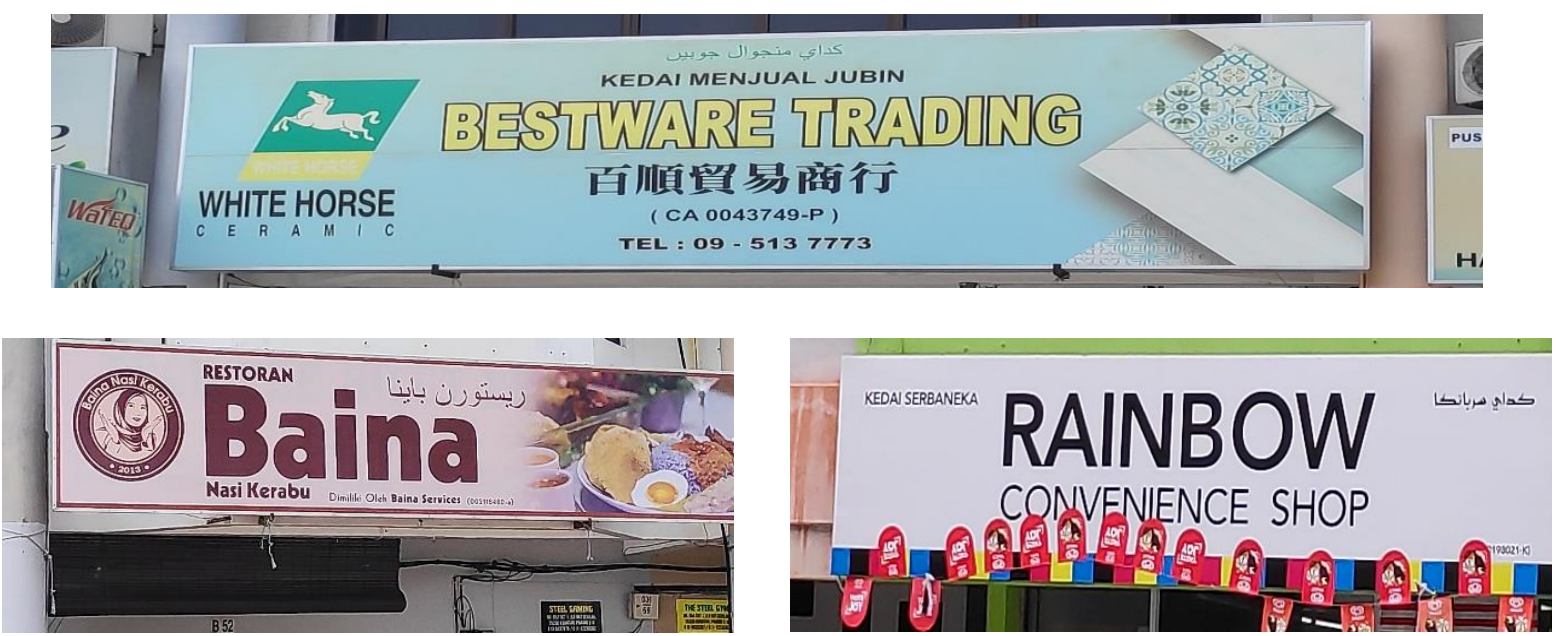

Figure 1: Samples of monolingual, bilingual and trilingual signs

After the patterns have been determined, all the signs are analysed and categorised according to which language(s) is used for each category. The data are treated quantitatively in terms of frequency counts for each category. Descriptive analysis is used to explain the findings.

\section{Findings and Discussion}

The analysis of the present study confirms the findings of other studies in the literature with regards to language use in the business domain. Regardless of the language policy stipulated 
by the authority, language use in business seems to adhere more to freedom and personal choice. The following section presents and discusses the findings.

\section{Patterns of Language Use in Shop Signs}

The data show a clear pattern of monolingual, bilingual and multilingual language use in the shop signs. As can be seen in Table 2, there are evidence of monolingual (48 or $26.8 \%$ ), bilingual (103 or $57.5 \%$ ) and multilingual ( 28 or $15.7 \%$ ) in the shop signs. Samples of the signs are shown in Figures 2, 3 and 4.

Table 2: Patterns of Language Use in Shop Signs in Kuantan

\begin{tabular}{|c|c|c|}
\hline Category & Number of Signs & Examples \\
\hline Monolingual & $48 \quad(26.8 \%)$ & Pro Tyre - One Stop Centre \& Services centre \\
\hline Bilingual & $103(57.5 \%)$ & Sekilau Tom Yam Corner \\
\hline Multilingual & $28 \quad(15.7 \%$ & $\begin{array}{l}\text { Pusat Rawatan Kecantikan dan Solekan Bai Nian } \\
\text { 白念 }\end{array}$ \\
\hline
\end{tabular}
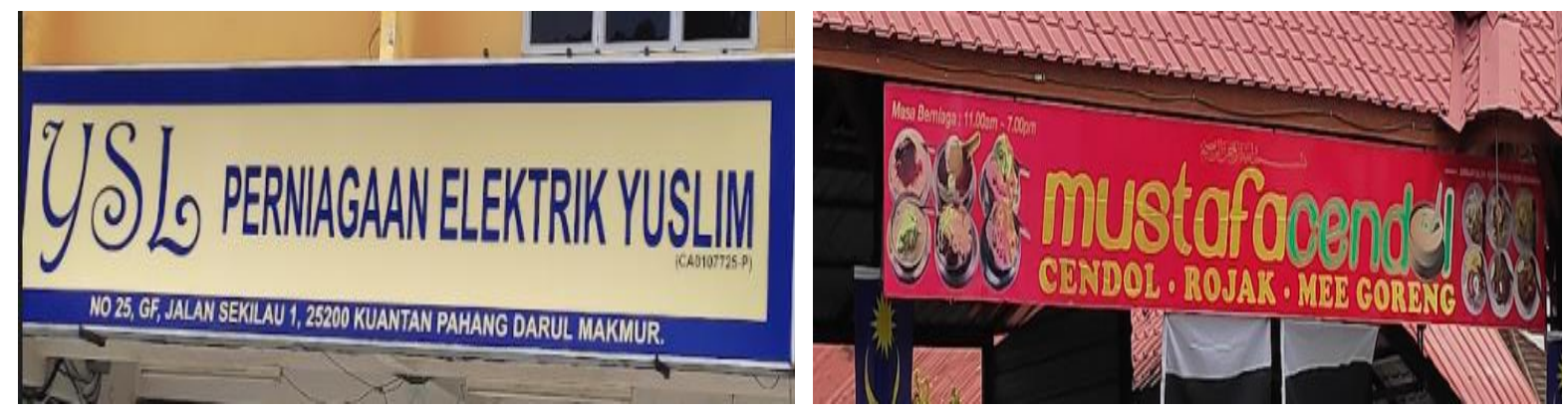

Figure 2: Monolingual Shop Signs in Kuantan
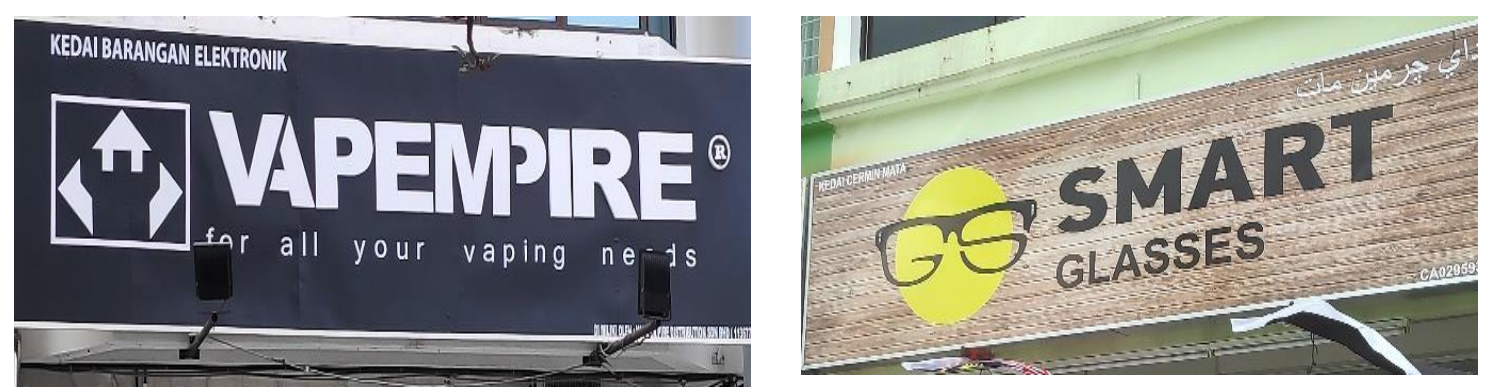

Figure 3: Bilingual Shop Signs in Kuantan
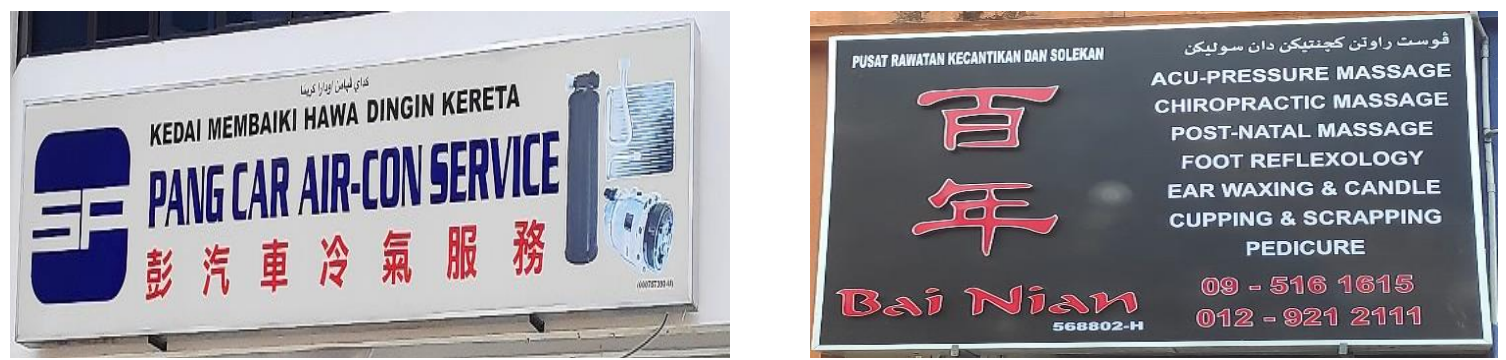

Figure 4: Multilingual Shop Signs in Kuantan

The analysis indicates that despite the mandatory rule for the use of BM in public signs and having the Malays as the dominant group of population in the area, the number of bilingual and multilingual signs combined far exceeded the number of monolingual signs. This shows 
that in business, what matters the most is catering to the needs of potential customers, which in the case of Malaysia, will be the multilingual community. Thus, regardless of the statistical differences in the population by race, business proprietors are actually targeting all potential customers in the community whom they believe would have the purchasing power. As Saleem (2018) points out, when a language is present or absent on a public sign, it can reveal the status of a language and its speakers in a society. This is in line with Landry and Bourhis' (1997) claim that the choice of public signage language shows the status in the community if the language used and as such indicates the relative power and status of the linguistic communities in a particular or specified territory.

It can also be implied that the evidence of the multilingual language in most of the signs is actually signifying the business community solidarity of which language(s) is deemed appropriate for their businesses despite the mandatory policy. As observed by Wang and Xu (2018), this not only shows the realities of language use, but acts as a window to see the tension between practices, beliefs, and managements in language policy, which is quite usual in a multilingual society. Manan et al (2015) also concur that when languages like English, Mandarin and Tamil make their appearance besides the national language of BM, it signifies group solidarity in a multilingual society like Malaysia.

\section{Language Preference in Shop Signs}

The analysis on monolingual signs shows that only three languages are used. As shown in Table 2, out of 48 monolingual shop signs in the research area, $30(62.5 \%)$ are in BM, while only 18 of them are in English. There is no monolingual shop sign in Chinese, Tamil and other languages.

Table 3: Language Preferences in Monolingual Shop Signs in Kuantan

\begin{tabular}{ll}
\hline Language & Number of Signs \\
\hline BM & $30(62.5 \%)$ \\
\hline English & $18(37.5 \%)$ \\
\hline Chinese & $0(0 \%)$ \\
\hline Tamil & $0(0 \%)$ \\
\hline Others & $0(0 \%)$ \\
\hline Total & $48(100 \%)$ \\
\hline
\end{tabular}

As for the bilingual signs, out of 103 shop signs, the combination of BM and English seems to be the most preferred languages among the business owners ( 89 or $86.4 \%$ ). This is followed by a small percentage of 9 or $8.7 \%$ that opt for English and Chinese. Only $4.9 \%$ of the signs contain a combination of BM and Tamil, and other languages like English and Arabic (Figure $5)$. 


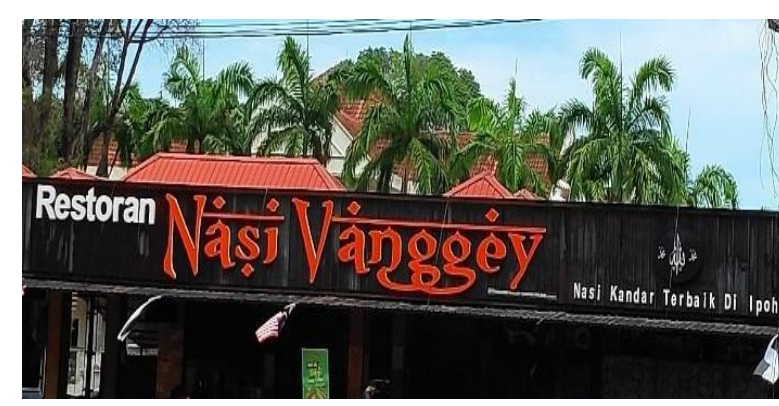

(a)

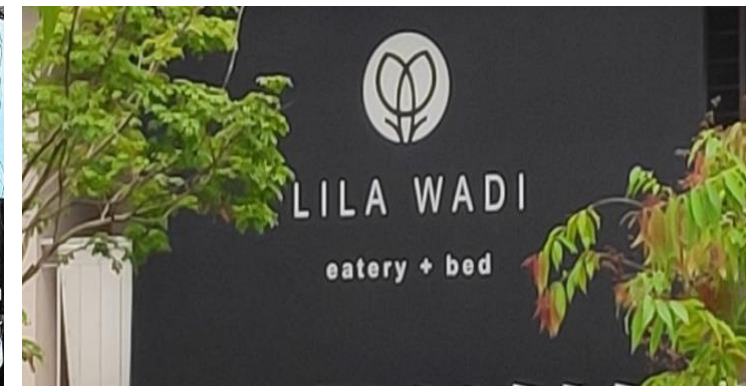

(b)

Figure 5: Bilingual Signs of BM and Tamil (a) and English and Arabic (b)

Table 4 shows the preferred languages in the multilingual signs. The 28 multilingual signs show that the combination of BM, English, and Chinese is the most preferred compared to other languages ( 25 or $89.3 \%$ ). This is followed by the combination of BM, English and Arabic with 2 (7.1\%). The combination that has the least amount of number is BM, English, Chinese, and Tamil with $1(3.6 \%)$.

Table 4: Language Preferences in Multilingual Shop Signs in Kuantan

\begin{tabular}{ll}
\hline Languages & Number of Signs \\
\hline BM + English + Chinese & $25(89.3 \%)$ \\
\hline BM + English + Arabic & $2(7.1 \%)$ \\
\hline BM + English + Chinese + Tamil & $1(3.6 \%)$ \\
\hline TOTAL & $28(100 \%)$ \\
\hline
\end{tabular}

Although Kuantan has been proclaimed as a city, the language use in the shop signs is still limited to BM, English, Chinese, Tamil and a couple of foreign languages like Arabic. Unlike other major cities like Kuala Lumpur, which showcase more vibrant use of international languages like Japanese, Korean, French, Spanish among others, the analysis in the present study indicates that BM, English and Chinese are still the language(s) of preference among the business proprietors in this part of the country. BM, being the national language and the language used and spoken by most of the population, is the obvious choice for the shop signs. Likewise, English, being the second most important language in the country and understood by most of the population is also preferred in the business domains. Furthermore, the development of the tourism sector and foreign businesses, coupled with the enhancement of social and technology have also accounted for the prominence of English in the signs. As put forward by Manan et al. (2015), English occupies a prominent place on the signboards which shows that the city is a tourist spot and signals the international and westernized outlook of the city. Chinese is also one of the preferred languages as it has always been considered as the language of business. Having Chinese in the shop signs may bring some commercial benefits to the business.

Factors Influencing Language Use and Preference on the Shop Signs

The data have shown that language use and preference in the shop signs cannot be easily controlled or regulated by any policy. Rather, it is shaped by economic values, and personal freedom and choice. 
In terms of economic values, language choice is closely related to the type of business or merchandise offered. For example, in the sign 'Restoran Nasi Vanggey', the Tamil word 'vanggey' is maintained to keep the authenticity of the dish. Having it translated to another language may not lend its authentic 'feel' to the customer. Similarly, 'Vapempire' which is a combined word from 'vape' and 'empire' is used as no word in other language can suitably replace the word 'vape'.

In addition, certain languages are preferred because it can lend a touch of modernity, sophistication and exclusivity to the shops. This is particularly true when it comes to fashion stores. 'Boutique', 'fashionista' and 'collection' are examples of words that are commonly found in the shops merchandising clothing. In addition, Arabic words like 'hijab' and 'hijabista' are also found in the shop signs that sell headscarves or Muslim clothing. Such choice of language is a pragmatic method of associating the items sold and the Muslim origin, which is from the Arab countries.

The analysis also shows that Chinese is mostly found in the signs when the owners are of the Chinese race. Pragmatically, this may function as an announcement to the public or potential customers that the owner of the shop is a Chinese. This may either be to inform the customers the skills and merchandise that the Chinese are well-known for, or to inform the fellow Chinese of the existence of their shops, thus, lending support to their business.

\section{Conclusion}

This study has shown that language use and preferences cannot be simply regulated by any policy. While language use on official signs can be mandated by the authority, language use in other domains is the matter of personal choice and freedom. The findings have shown that other languages are competing against the stipulated BM in the shop signs.

In the business domain, the choice and preferences may be motivated by a myriad of purposes. The obvious reasons would be the economic and pragmatic ones. With the development of Kuantan as the commercial hub and the door to the East-Coast economic development, the choice will, no doubt, remain with the business owners. Though the authority has its own requirements on what should or should not be present in a signboard, business owners may still want to have their personal touch to their shop signs and make them their personal signature among other businesses in the city.

This study is important in affirming that language preference is not only done according to stated policies, but also according to the business owner's wants. They desire their own personal touch to the shop signs, keeping in mind the potential customers the shop signs may attract. Further study could be done on other cities situated in other East Coast states and also to determine if the same outcomes could be obtained.

\section{References}

Ariffin, K., De Mello, G., Husin, M. S., Anuardin, A. A. S. (2019). Linguistic landscapes in Putrajaya: Competing codes and choice. Proceedings of the Regional Conference on Science Proceedings of the Regional Conference on Science, Technology and Social Sciences (RCSTSS 2016), Singapore: Springer. pp. 431-442.

Bolton, K. (2012). World Englishes and linguistic landscapes. World Englishes, 31(1), 30-33. 
David, M. K., \& Manan, S. A. (2016). Language ideology and the linguistic landscape: A study in Petaling Jaya, Selangor, Malaysia. Linguistics and the Human Sciences, 11(1), 51-66.

Gorter, D. (Ed.). (2006). Linguistic landscape: A new approach to multilingualism. Multilingual Matters.

Hasan, N. H., Soo, C. K. Y., \& Jangga, R. (2015). A multifactorial sociolinguistic analysis of SME business company naming in Malaysia. Procedia Economics and Finance, 31, 228 - 236.

Huebner, T. (2006). Bangkok's linguistic landscapes: Environmental print, codemixing and language change. International journal of multilingualism, 3(1), 31-51.

Husin, M. S., Ariffin, K., De Mello, G., Omar, N. H., \& Anuardin, A. A. S. (2019). Mapping the linguistic landscape of Kuala Lumpur. International Journal of Modern Languages and Applied Linguistics. 3(4), 1-9.

Jaworski, A., \& Thurlow, C. (2010). Introducing semiotic landscapes. Semiotic landscapes: Language, image, space, $1,40$.

Khosravizadeh, P., \& Sanjareh, H. B. (2011). English Shop Signs and Brand Names. BRAND. Broad Research in Accounting, Negotiation, and Distribution, 2(2), 32-40.

Landry, R., \& Bourhis, R. (1997). Linguistic landscape and ethnolinguistic vitality: An empirical study. Journal of language and social psychology, 16, 23_49.

Manan, S. A., David, M. K., Dumanig, F. P., \& Naqeebullah, K. (2015). Politics, economics and identity: Mapping the linguistic landscape of Kuala Lumpur, Malaysia. International Journal of Multilingualism, 12(1), 31-50.

Saleem, A. (2018). Linguistic Landscape: A Study of Signage at Public Museum in Cardiff. Putaj Humanities \& Social Sciences, 25(1).

Shang, G., \& Guo, L. (2016). Linguistic landscape in Singapore: What shop names reveal about Singapore's multilingualism. International Journal of Multilingualism, 14(2), 183-201.

Shohamy, E. G. (2006). Language policy: hidden agendas and new approaches. Routledge.

Tan, P. K. (2011). Subversive engineering: Building names in Singapore. In Engineering earth (pp. 1997-2011). Springer, Dordrecht.

Omar, N. H., Anuarudin, A. A. S., Husin, M. S., \& Ariffin, K. (2020). Language choice and preferences: Mapping the linguistic landscape of Sentul, Malaysia. EnvironmentBehaviour Proceedings Journal. 5(SI3), Dec, Special Issue No. 3. 25-30.

Wang, X., \& Xu, D. (2018). The mismatches between minority language practices and national language policy in Malaysia: A linguistic landscape approach. Kajian Malaysia 36(1): 105-125. 